\title{
Penyidikan Tindak Pidana Pemilihan Umum Gubernur dan Wakil Gubernur Sumatera Utara Tahun 2018
}

\section{Criminal Investigation of The Election of Governors and Deputy Governors of North Sumatra in 2018}

\author{
Agustami1 $^{1}$, Triono Eddy ${ }^{2}$, Mahmud Mulyadi ${ }^{3}$ \\ 1)Program Studi Magister Hukum Pidana, Fakultas Hukum, \\ Universitas Muhammadiyah Sumatera Utara, Indonesia \\ 2) Program Studi Ilmu Hukum, Fakultas Hukum, Universitas Muhammadiyah Sumatera Utara, \\ Indonesia
}

3) Program Studi Hukum Pidana, Fakultas Hukum, Universitas Sumatera Utara, Indonesia

Diterima: 28 Februari 2020; Disetujui: 13 Maret 2020; Dipublish: 23 Maret 2020

*Coresponding Email:agustami.lubis@gmail.com

\begin{abstract}
Abstrak
Pemilihan gubernur dan wakil gubernur Sumatera Utara pada tahun 2018 merupkan proses memilih orang untuk menduduki jabatan melalui mekanisme dan proses demokrasi yang jujur dan adil. Dalam proses pelaksanaan pemilu pemilu banyak terjadi pelanggaran-pelanggaran baik pelanggaran bersifat administrasi, maupun bersifat tindak pidana. Penelitian ini bertujuan untuk untuk menganalisis pengaturan tindak pidana pemilu pada pemilihan gubernur dan wakil gubernur propinsi Sumatera Utara menurut UU No. 10 Tahun 2016. Pasangan calon Jopinus Ramli (JR) Saragih dan Ance Selian yang dibatalkan KPU propinsi terkait tindak pidana dalam bentuk pidana pemalsuan surat dokumen, sebagaimana disebutkan dalam Pasal 184 dengan UU No. 10 Tahun 2016 tentang Pemilihan Gubernur, Bupati, dan Walikota, dan mengetahui proses penyidikan tindak pidana pemilihan umum gubernur dan wakil gubernur provinsi Sumatera Utara. Hasil penulisan ini menunjukan bahwa peraturan dalam tindak pidana pemilu gubernur dan wakil gubernur merujuk pada UU No. 10 Tahun 2016 dan proses penyelidikan oleh Kepolisian atas temuan BAWASLU menunjukan bukti-bukti, fakta hukum dan saksi yang menyimpulkan terjadinya tindak pidana pemalsuan dokumen dan KPU membatalkan pasangan calon JR Saragih dan Ance Selian.
\end{abstract}

Kata kunci: Tindak Pidana, Pemilihan Gubernur

\begin{abstract}
The election of the governor and deputy governor of North Sumatra in 2018 is the process of selecting people to hold office through honest and fair democratic mechanisms and processes. In the process of carrying out general elections, there are many violations, both administrative and criminal violations. This study aims to analyze the regulation of election criminal acts in the election of the governor and deputy governor of the province of North Sumatra according to Law No. 10 of 2016. The pair of candidates Jopinus Ramli (JR) Saragih and Ance Selian were canceled by the provincial KPU in relation to criminal acts in the form of falsified documents, as stated in Article 184 with Law No. 10 of 2016 concerning the Election of Governors, Regents and Mayors, and is aware of the criminal investigation process of the general election of the governor and deputy governor of the province of North Sumatra. The results of this writing indicate that the regulations in the election and governor vice governor criminal acts refer to Law No. 10 of 2016 and the investigation process by the Police on the findings of BAWASLU showed evidence, legal facts and witnesses which concluded the criminal acts of falsification of documents and the KPU canceled candidate pair JR Saragih and Ance Selian.
\end{abstract}

Keywords: Criminal Acts, Election of Governors

How to Cite: Agustami, Eddy, T. Mulyadi, M. (2020). Penyidikan Tindak Pidana Pemilihan Umum Gubernur dan Wakil Gubernur Sumatera Utara Tahun 2018. Journal of Education, Humaniora and Social Sciences (JEHSS). 2 (3): 607-618. 


\section{PENDAHULUAN}

Kegiatan Pemilihan Umum (Pemilu) di Indonesia meripakan wujud dari pelaksanaan kedaulatan rakyar yang dulakukan secara langsung, umum, bebas rahasia, jujur dan adil berdasarkan Pancasila dan Undang-Undang Dasar Republik Indonesia Tahun 1945 pada Pasal 1 ayat (2) yang menyatakan bahwa "Kedaulatan berada di tangan rakyat dan dilaksanakan berdasarkan Undang-Undang Dasar." Sebagai perwujudan kedaulatan rakyat, maka rakyat melalui Pemilihan Umum yang merupakan salah satu bentuk dan cara yang paling nyata untuk melaksanakan demokrasi. Jika demokrasi diartikan sebagai pemerintahan dari, oleh, dan untuk rakyat, maka cara rakyat untuk menentukan pemerintahan itu dilakukan dengan Pemilu.

Pemilu kepala daerah merupakan proses memilih orang untuk menduduki sebuah jabatan. Sistem pelaksanaan pemilu memiliki mekanisme dan proses demokrasi yang jujur dan adil yang dijamin oleh sejumlah peraturan perundang-undangan. Sesuai Pasal 18 ayat (4) UUD Negara Republik Indonesia Tahun 1945 mengatur bahwa: "Gubernur, Bupati, dan Walikota masing-masing sebagai kepala pemerintah daerah provinsi, kabupaten dan kota dipilih secara demokratis" Pasal 18 Undang-undang Dasar Republik Indonesia Tahun 1945 merupakan dasar penyelenggaraan pemerintahan secara nasional, dalam hal ini termasuk pemerintahan daerah. Dalam Pasal 18 Undang-undang Dasar Republik Indonesia Tahun 1945 diatur tentang pembagian daerah ke dalam provinsi, kemudian provinsi dibagi ke dalam kabupaten dan kota.

Pembagian daerah baik provinsi, kabupaten dan kota mempunyai pemerintahan sendiri. Di samping itu, juga diatur pemerintahan daerah itu dilaksanakan menurut asas otonomi dan tugas pembantuan. Untuk menyelenggarakan pemerintahan, daerah yang bersangkutan dipimpin oleh seorang kepala daerah, baik di provinsi maupun di kabupaten/kota. Untuk propinsi, kepala daerah disebut gubernur dan untuk kabupaten, kepala daerah disebut bupati dan untuk kota, kepala daerah disebut walikota.

Seluruh pelaksanaan sistem pemilu pada pemilihan gubernur dan wakil gubernur di Indonesia harus diselenggarakan berdasarkan Undang-undang Dasar Republik Indonesia tahun 1945 dan aturan perundang-undangan yang telah ditetapkan di Indonesia serta wajib diselenggarakan setiap 5 (lima) tahun sekali, hal ini tersebut dalam Pasal 22 E ayat (1) Undang-Undang Dasar Negara Republik Indonesia Tahun 1945, yaitu: 
"Pemilihan umum dilaksanakan secara langsung, umum, bebas, rahasia, jujur dan adil setiap 5 (lima) tahun sekali."

Pelaksanaan pemilu yang berkualitas dipengaruhi oleh banyak faktor-faktor yang diantaranya adalah kesadaran politik, tingkat pendidikan, sosial ekonomi masyarakat, keberagaman ideologi, etnik dan suku, kematangan partai, dan kondisi geografis dimana faktor-faktor itu memiliki implikasi-implikasi yang khas terkait perilaku memilih masyarakat sebagaimana sistem pemilu itu sendiri (Joko.J Ptihatmoko: 2008)

Pemilu pemilihan gubernur dan wakil gubernur yang telah diselenggarakan hingga sampai dengan saat ini, bahwa dalam proses pelaksanaan pemilu pemilihan gubernur dan wakil gubernur di Indonesia banyak terjadi kemungkinan adanya pelanggaranpelanggaran, baik pelanggaran yang bersifat administratif maupun pelanggaran yang berupa tindak pidana yang disebabkan juga oleh berbagai faktor lain yang mempengaruhi. Suatu tindak pidana dalam suatu pemilu merupakan suatu perbuatan pidana yang di dalamnya terdapat unsur kejahatan maupun unsur pelanggaran yang harus dipertanggungjawabkan oleh orang yang melakukan perbuatan yang melanggar nilai-nilai pemilu yang demokratis.

Pemilihan kepala daerah pasangan calon gubernur dan wakil gubernuur provinsi Sumatera Utara pada tahun 2018, awalnya terdapat 3 (tiga) bakal pasangan calon gubernur dan wakil gubernur yang melakukan pendaftaran di Komisi Pemilihan Umum (KPU) Sumatera Utara untuk ikut pemilu pemilihan gubernur dan wakil gubernur propinsi Sumatera Utara.

Bakal pasangan calon tersebut, adalah sebagai berikut:1) Pasangan calon gubernur dan wakil gubernur Letjen (Purn) Edy Rahmayadi dan Musa Rajeckshah; 2) Pasangan calon gubernur dan wakil gubernur Djarot Saiful Hidayat dan Sihar Sitorus; 3) Pasangan calon gubernur dan wakil gubernur Jopinus Ramli (JR) Saragih dan Ance Selian (Jefris Santama:2018)

Dari 3 (tiga) pasangan calon yang mendaftar tersebut, KPU Sumatera Utara kemudian hanya menetapkan 2 (dua) bakal pasangan calon gubernur dan wakil gubernur yang ikut dalam pemilu pemilihan gubernur dan wakil gubernur propinsi Sumatera Utara di tahun 2018, yaitu: pasangan calon Letjen (Purn) Edy Rahmayacdi dan Musa Rajeckshah (Ijeck), serta Pasangan calon Djarot Saiful Hidayat dan Sihar Sitorus. 
KPU Sumatera Utara mengeluarkan keputusan bahwa terhadap bakal pasangan calon gubernur dan wakil gubernur Provinsi Sumatera Utara JR Saragih dan Ance Selian dinyatakan batal dan tidak dapat untuk ikut pemilihan gubernur dan wakil gubernur propinsi Sumatera Utara karena ketidaklengkapan dokumen. Adapun deskriptif kasus adalah sebagai berikut: KPU Sumatera Utara memutuskan pasangan bakal calon gubernur dan wakil gubernur Provinsi Sumatera Utara, JR Saragih dan Ance Selian tidak memenuhi syarat karena tidak mematuhi putusan Badan Pengawas Pemilu (BAWASLU) Sumatera Utara terkait legalisir ulang fotokopi ijazah Sekolah Menengah Atas (SMA) (Husein Abdulsalam:2018).

KPU Provinsi Sumatera Utara menganggap Jopinus Ramli (JR) Saragih tidak menjalankan putusan BAWASLU Sumatera Utara untuk melegalisir ulang fotokopi SMA atas namanya. KPU Provinsi Sumatera Utara juga menilai tindakan JR Saragih tidak sesuai dengan amar putusan BAWASLU Sumatera Utara yang hanya memberikan melegalisir Surat Keterangan Pengganti Ijazah (SKPI) SMA-nya karena JR Saragih mengemukakan kepada KPU bahwa Ijazah aslinya telah hilang dan menyatakan SKPI memiliki kekuatan yang sama dengan fotokopi ijazah (Husein Abdulsalam:2018)

Pemilu pemilihan gubernur dan wakil gubernur provinsi Sumatera Utara yang telah dilaksanakan pada Maret 2018, dimana 1 (satu) pasangan bakal tersebut dibatalkan oleh KPU Sumatera Utara karena telah melakukan perbuatan pelanggaran pidana terhadap prasyarat formal, melakukan tindakan-tindakan yang melakukan ketentuan-ketentuan yang telah ditetapkan dalam pelaksanaan pemuli pada pemilihan pasangan gubernur dan wakil gubernur provinsi Sumatera Utara. Berdasarkan pernyataan KPU Sumatera Utara dengan dibatalkannya bakal calon gubernur dan wakil gubernur provinsi Sumatera Utara JR Saragih dan Ance Selian, kemudiann pihak Kepolisian Republik Indonesia Sumatera Utara menindaklanjuti dengan melakukan penelusuran melalui proses penyidikan terhadap JR Saragih yang diduga telah melakukan suatu pelanggaran tindak pidana dalam pemilu pemilihan kepada daerah provinsi Sumatera Utara.

Dugaan tindak pidana pemilihan gubernur dan wakil gubernur Provinsi Sumatera Utara atas JR Saragih diduga melakukan pemalsuan surat, yakni; ijazah/Surat Tanda Tamat Belajar (STTB) dalam pendaftaran pencalonan Gubernur Sumatera Utara tahun 2018 yang sebagaimana diatur Pasal 184 Undang-Undang Nomor 1 Tahun 2015 Tentang Penetapan Peraturan Pemerintah Pengganti Undang-Undang Nomor 1 Tahun 2014 
Menjadi Undang-Undang sebagaimana dirubah dengan Undang-Undang Nomor 8 tahun 2015.

Diketahui melalui BAWASLU Sumatera Utara pada saat sidang sengketa pemilihan gubernur dan wakil gubernur provinsi Sumatera Utara Tahun 2018, KPU Sumatera Utara mengajukan bukti surat berupa fotocopy legasir ijazah SMA atas nama Jopinus Ramli Saragih yang menjelaskan bahwa fotocopy legalisir Ijazah SMA no 01 OC oh 0373795 tertanggal 26 Mei 1990 atas nama Jopinus Ramli Saragih (alias JR Saragih) telah digunakan sebagai persyaratan pada saat pendaftaran Calon Gubernur dan Wakil Gubernur Sumut Tahun 2018.

Berdasarka uraian tersebut, maka upaya penyelesaian tindak pidana dalam suatu pemilu harus dilakukan sesuai dengan peraturan perundang-undangan yang berlaku, dimana menempatkan Kepolisian sebagai penyelidikan dan penyidikan proses pemeriksaan adanya suatu tindak pidana dalam pemilu, berikutnya Kejaksaan untuk melakukan penuntutan, dan Pengadilan untuk mengadili kasus, dan seterusnya sesuai proses hukum acara pidana sebagaimana diatur didalam Kitab Undang-undang Hukum Acara Pidana (KUHAP).

Tindak pidana pemilihan Kepala Daerah adalah perbuatan atau tindakan yang dapat dinilai sebagai tindak pidana berdasarkan Undang-Undang Pemilihan Kepala Daerah No. 10 tahun 2016. penyelenggaraan pemilihan Kepala Daerah hanya dilakukan sesuai dengan tahap dan ajdwal yang sudah ditetapkan yaitu hanya sekali dalam lima tahun sesuai dengan siklus proses demokrasi. Tindak pidana dalam Pemilihan Kepala Daerah dapat dilakukan oleh pasangan calon, partai politik, tim sukses, para saksi, pasangan calon di tempat pemungutan suara dan pendukung pasangan calon (Magdalena Laurenzia, 2017).

Proses Penanganan Perkara Tindak Pidana Dalam Pemilihan Kepala Daerah, yaitu: melalui sentra Gabungan Penegak Hukum Terpadu (GAKKUMDU) yang terdiri dari Badan Pengawas Pemilihan Umum, Kepolisian Republik Indonesia dan Kejaksaan Negara. Dengan melaksanakan tugasnya sesuai laporan masyarakat atau temuan langsung di lapangan berdasarkan rekomendasi Badan pengawas pemilu (Bawaslu) di tingkat Provinsi dan Panitia Pengawas (Panwas) di tingkat Kabupaten/Kota yang selanjutnya diteruskan kepada pihak kepolisian dan ditindak lanjuti oleh pihak kepolisian dalam tenggang waktu 14 hari. Apabila, terdapat barang bukti yang cukup 
maka pihak kepolisian melimpahkan kepada pihak kejaksaan dan pihak kejaksaan wajib melimpahkan perkara tindak pidana dalam pilkada selama 5 hari kerja. Apabila tenggang waktu tersebut baik pada pihak kepolisian dan kejaksaan melebihi waktu yang telah ditentukan oleh Undang-Undang maka gugurlah hak hak penuntutan karena kadaluarsa atau lewat waktu calon (Laurenzia, 2017).

Tujuan penelitian ini adalah untuk mengetahui tindak pidana pemilihan umum gubernur dan wakil gubernur menurut Undang-Undang No. 10 Tahun 2016 dan proses penyidikan tindak pidana pemilihan umum gubernur dan wakil gubernur provinsi Sumatera Utara.

\section{METODE PENELITIAN}

Dalam penelitian ini, penulis menggunakan jenis penelitian hukum normatif dan penelitian empiris. Teknik pengumpulan data dilakukan dnegan sutudi kepustakaan untuk memperoleh data dengan membaca, menelaah, mengklarifikasi, mengidentifikasi dan melakukan pemahaman terhadap bahan-bahan hukum berupa peraturan perundangn-undangan serta buku-buku literarur yang relevan dengan penelitian ini. Penelitian empiris dengan teknik pengumpulan data lapangan dilakukan dengan mengambil data yang berkaitan dengan kasus tindak pidana pemilihan gubernur dan wakil gubernur pasangan calon JR Saragih dan Ance di Kepolisian Negara Republik Indonesia Daerah Sumatera Utara Direktoral reserse Kriminal Khusus.

Penelitian hukum normatif, disebut sebagai penelitian perpustakaan atu studi dokumen, karena lebih banyak dilakukan terhadap data yang bersifat sekunder yang ada di perpustakaan (Ediwarman, 2014). Penelitian hukum normatif juga mengacu kepada aturan-aturan hukum, norma-norma hukum yang terdapat baik di dalam ketentuan perundang-undangan maupun di dalam putusan pengadilan. Penelitian hukum empiris merupakan penelitian hukum yang memakai sumber data primer, yang mana data yang diperoleh berasal dari eksperimen dan observasi (Ediwarman, 2014). Teknik pengambilan dan pengumpulan data dilakukan dengan cara studi kepustakaan (library research) dan studi lapangan (field research) (Soekanto, 1990). 


\section{HASIL DAN PEMBAHASAN}

\section{Tindak Pidana Pemilu menurut Undang-Undang No. 10 Tahun 2016}

Fenomena yang muncul ternyata di berbagai daerah banyak terjadi penyimpangan, di mana beberapa calon kepala daerah melakukan perbuatan curang memanipulasi prasyarat formal, melakukan tindakan-tindakan yang kurang terpuji dengan menghalalkan segala cara agar dapat terpilih, dan atau melakukan tindakan yang melanggar ketentuan dalam pelaksanaan pemilihan kepala daerah yang dapat dikategorikan sebagai tindak pidana (Aribowo, 1996).

Suatu perbuatan/tindakan yang dapat dinilai sebagai tindak pidana pemilu adalah perbuatan yang dikriminalisasi berdasarkan Undang-Undang Pemilu. Sesuai defenisi itu, juga dapat dipahami bahwa tindak pidana pemilu adalah pelanggaran terhadap suatu kewajiban, hal mana pelanggaran tersebut diancam sanksi pidana dalam UU Pemilu (Santoso, 2004)

Unsur-unsur dalam tindak pidana yaitu unusr objektif, dimana unsur yang terdapat di di luar si pelaku yang ada hubungannya dengan keadaan-keadandimnana tindakantindakan si pelaku ituharus dilakukan. Kemudian, unsur subjektif yang merupakan unsur yang melekat pada diri si pelaku yang dihubungkan dengan diri si pelaku trmasuk segala sesuatu yang terkandung di dalam hatinya (Prasetyo, 2015)

Jenis pelanggaran pidana pada pemilu pemilihan gubernur dan wakil gubernur dapat dilihat pada Pasal 135 ayat (1) UU No. 1 Tahun 2015 jo. UU No. 8 Tahun 2015 jo. UU No. 10 Tahun 2016 tentang Pemilihan Gubernur, Bupati, dan Walikota, yakni meliputi pelanggaran kode etik penyelenggara pemilihan, pelanggaran administrasi pemilihan, sengketa pemilihan, tindak pidana pemilihan, bentuk-bentuk dan sanksi-sanksi tindak pidana pemilu yang telah diatur dalam UU No. 10 Tahun 2016 tentang Perubahan kedua atas UU No. 1 Tahun 2015 Tentang Penetapan PERPU No. 1 Tahun 2014 Tentang Pemilihan Gubernur, Bupati, Dan Walikota Menjadi UU ialah Pasal 177A ayat (1) "Setiap orang yang dengan sengaja melakukan perbuatan melawan hukum memalsukan data dan daftar pemilih sebagaimana dimaksud dalam Pasal 58, dipidana dengan pidana penjara paling singkat 12 (dua belas) bulan dan paling lama 72 (tujuh puluh dua) bulan dan denda paling sedikit Rp12.000.000,00 (dua belas juta rupiah) dan paling banyak Rp72.000.000,00 (tujuh puluh dua juta rupiah)." Selanjutnya diatur dalam ketentuan Pasal 177B, Pasal 178A, 178B, 178C, 178D, 178E, 178F, 178G, 182A, 182B, 185A, 185B, 
186A, 187A, 187B, 187C, 187D, 190A, 193A, 193B, 198A UU No. 1 Tahun 2015 Tentang Penetapan PERPU No. 1 Tahun 2014.

Bentuk pelanggaran-pelanggaran pidana berdasarkan UU No. 10 Tahun 2016 yang telah diuraikan diatas, maka terkait tindak pidana pemilu pada pemilihan gubernur dan wakil wakil gubernur provinsi Sumatera Utara yang terjadi, yaitu tindak pidana dengan sengaja memberikan keterangan yang tidak benar atau menggunakan surat palsu seolaholah sebagai surat yang sah tentang suatu hal yang diperlukan bagi persyaratan untuk menjadi calon gubernur dan wakil gubernur. Bahwa ijazah/STTB No. 01 OC oh 0373795 atas nama JR Saragih yang telah dipergunakan untuk sebagai kelengkapan berkas dokumen pada saat pendaftaran pemilu pada pemilihan pasangan calon gubernur dan wakil gubernur propinsi Sumatera Utara, sebagaimana yang diatur oleh Pasal 184 UU No. 10 Tahun 2016.

Tandatangan Kepala Dinas Pendidikan DKI Jakarta, yang terdapat pada ijazah/STTB No. 01 OC oh 0373795 atas nama Jopinus Ramli (JR) Saragih adalah tidak benar. Kepala Dinas Pendidikan DKI Jakarta dalam keterangannya bahwa tandatangannya pada fotocopy ijazah/STTB yang dimaksud adalah tidak ada atau tidak pernah melakukan tandatangan. Kepala Dinas Pendidikan DKI Jakarta menyatakan bahwa bahwa tandatangan atas namanya sendiri pada ijazah/STTB No. 01 OC oh 0373795 milik Jopinus Ramli (JR) Saragih tidak ada kemiripan sama sekali dengan tandatangannya.

Sekretariat Dinas Pendidikan DKI Jakarta, menyatakan tidak pernah melakukan legalisir dan tidak pernah mengesahkan ijazah/STTB No. 01 OC oh 0373795 atas nama JR Saragih, hal ini sebagaimana dinyatakan oleh Dinas Pendidikan DKI Jakarta melalui Surat Sekretaris Dinas Pendidikan Provinsi DKI Jakarta Nomor 1710 /- 1.851.623, tanggal 26 Januari 2018, yang isinya menerangkan bahwa Dinas Pendidikan Provinsi DKI Jakarta tidak pernah melegalisir/mengesahkan Ijazah/STTB SMA Nomor 01 OC oh 037373795 Tahun 1990 atas nama Jopinus Saragih.

Pertanggungjawaban pidana terhadap tindak pidana pemilu pada pemilihan gubernur dan wakil gubernur propinsi Sumatera Utara tahun 2018, oleh JR SARAGIH calon gubernur dan wakil gubernur propinsi Sumatera Utara sesuai Pasal yang dikenakkan, yaitu: Pasal 184 UU No. 10 Tahun 2016 yang menyatakan:"Setiap orang yang dengan sengaja memberikan keterangan yang tidak benar atau menggunakan surat palsu seolah-olah sebagai surat yang sah tentang suatu hal yang diperlukan bagi 
persyaratan untuk menjadi calon gubernur, calon bupati, calon walikota, dipidana dengan pidana penjara paling singkat 36 (tiga puluh enam) bulan dan paling lama 72 (tujuh puluh dua) bulan dan denda paling sedikit Rp 36.000.0000,- (tiga puluh enamjuta rupiah) dan paling banyak Rp 72.000.000,- (tujuh puluh dua juta rupiah)."

\section{Proses Penyidikan Tindak Pidana Pemilihan Umum Gubernur Dan Wakil Gubernur Provinsi Sumatera Utara}

Tim penyidik khusus tindak pidana pemilu dibentuk sebelum pelaksanaan pemilu dan dibekali dengan pemahaman undang-undang pemilu yang harus dijadikan acuan untuk memberkas perkara tindak pidana pemilu. Adapun proses dalam penyidikan tindak pidana pemilu Polri mempersyaratkan penyidik yang tergabung di dalam satuan/unit penyidikan pelanggaran pemilihan umum (Sentra GAKKUMDU).

Sentra GAKKUMDU yaitu bertugas pada fungsi reserse kriminal, mempunyai mental dan dedikasi yang tinggi, ulet, aktif dan penuh tanggung jawab, menguasi dan memahami peraturan perundang-undangan yang berkaitan dengan pelaksanaan pemilihan umum, memiliki kemampuan dan pengalaman dibidang penyidikan perkara pidana dan mahir melakukan pemerikasaan perkara serta menguasi administrasi penyidikan, telah mengikuti pelatihan penyidikan pelanggaran pemilihan umum (Wawancara Penyidik Irsol Polda Sumut, 2018).

Laporan tindak pidana berupa pelanggaran pemilihan umum pada pemilihan gubernur dan wakil gubernur yang diterima polisi hanya berasal dari Badan Pengawas Pemilihan Umum. Artinya bahwa setiap pelanggaran pidana pemilu yang diketahui oleh masyarakat harus dilaporkan kepada Badan Pengawas Pemilihan Umum setelah itu Badan Pengawas Pemilihan Umum yang akan memfilter laporan tersebut apakah laporan itu termasuk pelanggaran pemilu dan kemudian melanjutkannya ke polisi umum (Wawancara Penyidik Irsol Polda Sumut, 2018).

Proses penyidikan hingga terbukti di pengadilan terkait pelanggaran pemilu maka peradilan yang berwenang memeriksa dan memutuskan sengketa pemilu haruslah juga siap mengadili sengketa atau pelanggaran pemilu. Dalam penanganan tindak pidana berupa pelanggaran pemilihan umum pada pemilihan kepala daerah oleh polisi. Polisi ditentukan untuk mengungkapkan pelanggaran pemilu dengan jangka waktu 14 hari yaitu tindakan penyelidikan, penyidikan dan berita acara pemeriksaan yang harus diserahkan kepada pihak kejaksaan untuk dilakukan penuntutan. Apabila berkas acara 
pemeriksaan dikembalikan oleh kejaksaan kepada polisi karena kurang lengkap maka dalam jangka waktu 3 hari, polisi diwajibkan untuk melengkapi berkas tersebut.

Jangka waktu yang sangat singkat inilah yang terkadang menjadi kesulitan jika dibandingkan dengan jangka waktu penyidikan yang diatur dalam Pasal 31 ayat (2) Peraturan Kepala Kepolisian Republik Indonesia Tentang Pengawasan dan Pengendalian Penanganan Perkara Pidana Di Lingkungan Kepolisian Negara Republik Indonesia. Dimana penyidik kepolisian dalam melaksanakan proses mempunyai batas waktu penyelesaian perkara dihitung sejak diterimanya Surat Perintah Penyidikan yang meliputi ;120 hari untuk penyidikan perkara sangat sulit, 90 hari untuk penyidikan perkara sulit, 60 hari untuk penyidikan perkara sedang, 30 hari untuk penyidikan perkara mudah umum (Wawancara Penyidik Irsol Polda Sumut, 2018).

Penyidik Sentra Penegakkan Hukum Terpadu (GAKKUMDU) provinsi Sumatera Utara telah melakukan pemeriksaan bahwa Jopinus Ramli (JR) Saragih dan dinyatakan telah melakukan tindak pidana dengan sengaja memberikan keterangan yang tidak benar atau menggunakan surat seolah-olah sebagai surat yang sah tentang suatu hal yang diperlukan sebagai persyaratan untuk menjadi calon gubernur pada pemilu pemilihan gubernur dan wakil gubernur propinsi Sumatera Utara tah un 2018 sebagaimana telah ditentukan oleh Pasal 184 UU No. 10 Tahun 2016.

Dugaan tindak pidana pemilihan menggunakan surat palsu dalam pencalonan Gubernur Sumatera Utara tahun 2018, diketahui tanggal 27 Februari 2018 dikantor BAWASLU Sumatera Utara pada saat Sidang Sengketa Pemilihan Gubernur dan Wakil Gubernur Provinsi Sumatera Utara Tahun 2018, KPU Sumatera Utara mengajukan Bukti Surat berupa fotocopy Legasir Ijazah SMA atas nama Jopinus Saragih yang menjelaskan bahwa fotocopy legalisir Ijazah SMA no 01 OC oh 0373795 tertanggal 26 Mei 1990 atas nama Jopinus Saragih telah digunakan sebagai persyaratan Calon gubernur dan wakil Gubernur Sumatera Utara Tahun 2018.

Setelah melakukan penyelidikan secara mendalam terhadap pihak-pihak terkait seperti pasangan calon gubernur dan wakil gubernur Sumatera Utara JR Saragih, KPU, Dinas Kependiidkan DKI Jakarta, berdasarkan alat bukti serta ketrangan saksi dan keterangan saksi ahli atas nama Dr. Mahmud Mulyadi, S.H.,M.Hum yang dimintai keterangan ahli oleh penyidik menerangkan menjelaskan berdasarkan fakta-fakta hukum di keterangan saksi-saksi bahwa JR Saragih dan barang-barang bukti, maka saksi 
ahli berpendapat pada kasus ini patut diduga unsur "Tentang suatu hal yang diperlukan bagi persyaratan untuk menjadi Calon Gubernur dan Wakil Gubernur.

Saksi ahli menjelaskan unsur keterangan yang dituangkan dalam suatu surat atau isi dari suatu surat tersebut, baik seluruhnya atau sebahagian bertentnagan dengan kebenaran. Sehingga suatu surat yang berisikan keterangan yang tidak benar tersebut disebut surat palsu.

Saksi Ahli menyatakan bahwa, seharusnya jika memang JR Saragih telah melakukan legalisir ijazah sesuai dengan prosedur hukum ke Dinas Pendidikan DKI Jakarta, maka yang tersangka harus lakukan adalah mengonfirmasi kembali ke Dinas Pendidikan DKI Jakarta dan bahkan bisa melakukan legalisir ualng untuk memenuhi persyaratan dengan waktu 3 (tiga) hari yang diberikan KPU Sumut, bukan justru menyerahkan surat dari Dinas Pendidikan DKI Jakarta dengan nomor:5396/-1.888.145 tertanggal 19 Januari 2018 perihal klarifikasi yang ditanda tangani oleh Kepala Dinas DKI Jakarta dengan cap stempel, yang ditunjukan kepada Direktur Eksekutif Dewan Pimpinan Daerah Partai Demokrat Sumut di Medan, yang ternyata surat tersebut juga tidak terdaftar di registrasi surat keluar Dinas Kependidikan DKI Jakarta.

Dengan tetap digunakan Legalisir Foto Copy Ijazah SMA tersebut oleh JR SARAGIH, maka tergambar bahwa perbuatan itu dilakukan secara sadar menghendaki dan mengetahui (de will en de witten), sehingga patut diduga memenuhi unsur subjektif berupa dengan sengaja umum (Wawancara Penyidik Irsol Polda Sumut:2018).

Berdasarkan pembahasan terhadap fakta-fakta / bukti dalam analisa kasus dan analisa yuridis tersebut maka terhadap JR. SARAGIH, patut diduga atau patut disangka telah melakukan Tindak Pidana Pemilihan menggunakan surat palsu dalam pencalonan Gubernur Sumatera Utara tahun 2018, , yang terjadi pada tanggal 09 s/d 10 Januari 2018 di Kantor KPU Sumut yang diketahui oleh Pelapor pada tanggal 27 Februari 2018 dikantor Bawaslu Sumut pada saat Sidang Sengketa Pemilihan Gubernur dan Wakil Gubernur Propinsi Sumatera Utara Tahun 2018.

\section{SIMPULAN}

Pengaturan tindak pidana pemilihan gubernur dan wakil gubernur Sumatera Utara paslon JR Saragih dan Ance Selian yang dibatalkan oleh KPU terkait tindak pidana dalam bentuk pemalsuan surat dokumen, sebagaimana disebutkan dalam Pasal 184 dengan UU 
No. 10 Tahun 2016 tentang Pemilihan Gubernur, Bupati, dan Walikota. Pasal 184 UU No. 1 Tahun 2015 yang menyatakan telah melakukan tindak pidana dengan sengaja memberikan keterangan yang tidak benar atau menggunakan surat seolah-olah sebagai surat yang sah tentang suatu hal yang diperlukan sebagai persyaratan untuk menjadi calon gubernur pada pemilu pemilihan gubernur dan wakil gubernur propinsi Sumatera Utara tahun 2018. Proses penyidikan berdasarkan hasil temuan BAWASLU dengan faktafakta hukum dan alat bukti serta keterangan saksi ahli diserahkan kepada pihak Kepolisian untuk ditindaklanjuti secara hukum.

\section{DAFTAR PUSTAKA}

Abdulsalam, Husein. Faktor Yang Membuat Djarot Kalah dari Edy di Pilgub Sumut 2018. https://tirto.id/faktor-yang-membuat-djarot-kalah-dari-edy-di-pilgub-sumut-2018-cM7n, 19 Desember 2018

Aribowo, (1996). Mendemokratiskan Pemilu, Elsam, Jakarta

Berita Acara Pemeriksaan Kepolisian Negara Republik Indonesia Daerah Sumatera Utara, Direktorat Reserse Kriminal Umum, tertanggal 21 Maret 2018

Ediwarman. (2014). Monograf Metodologi Penelitian Hukum (Panduan Penelitian Tesis dan Disertasi). Medan: Program Pascasarjana Universitas Muhammadiyah Sumatera Utara

Gaffar, J.M. (2012). Politik hukum Pemilu. Jakarta: Konstitusi Press Konpress

Laurenzia, M, (2017), Kajian Yuridis Terhadap Tindak Podana Pemilihan Kepala Daerah, Lex Administratum, Vol. v/No. 9/Nov/2017

Prasetyo, Teguh. (2015). Hukum Pidana, Rajawali Pers, Jakarta

Prihatmoko, J.J, (2008). Mendemonstrasikan Pemilu dari Sistem Elemen Taktis, Yogyakarta: Pustaka Pelajar

Resume Perkara Atas Nama Jopinus Ramli Saragih, di Direktorat Reserse Kriminal Umum Kepolisian Negara Republik Indonesia Daerah Sumatera Utara

Santama, Jefris. KPU Tetapkan 2 Pasangan Peserta Pilgub Sumut, JR Saragih Tak Lolos. https://news.detik.com/berita/3862715/kpu-tetapkan-2pasangan-peserta-pilgub sumut-jrsaragih-tak-lolos, 20 Desember 2018

Santoso, T., dkk., (2006). Penegakan Hukum Pemilu, Praktik Pemilu 2004. Kajian Pemilu 2009-2014, Perkumpulan Untuk Pemilu dan Demokrasi, Jakarta

Santoso, T. (2006). Tindak Pidana Pemilu, Sinar Grafika. Yogyakarta

Soekanto, S. (1986). Pengantar Penelitian Hukum. UI Press. Jakarta

Undang-Undang Dasar Negara Republik Indonesia Tahun 1945 Amandemen Ke III Pasal 18 UUD Negara Republik Indonesia Tahun 1945

Undang-Undang Nomor 10 Tahun 2016 tentang Perubahan Kedua Atas UU No. 1 Tahun 2015 Tentang Penetapan Peraturan Pengganti Undang-Undang No. 1 Tahun 2014 Tentang Pemilihan Gubernur, Bupati, Dan Walikota Menjadi Undang-Undang.

Undang-undang Nomor 8 tahun 2015 tentang Perubahan Undang-undang Nomor 1 tahun 2015 tentang penetapan Peraturan Pemerinta Pengganti Undangundang Nomor1 tahun 2014 tentang Pemilihan Gubernur, Bupati dan Walikota 